\title{
Farm-SAFE: the process of developing a plot- and farm-scale model of arable, forestry, and silvoarable economics
}

\author{
A.R. Graves ${ }^{1}$, P. J. Burgess ${ }^{1}$, F. Liagre ${ }^{2}$, J-P. Terreaux ${ }^{3}$, T. Borrel ${ }^{4}$, C. Dupraz ${ }^{4}$, J. Palma ${ }^{5}$ and \\ F. Herzog 6 \\ ${ }^{1}$ Cranfield University, Cranfield, Bedfordshire MK43 OAL, UK \\ ${ }^{2}$ Assemblée Permanente des Chambres d'Agriculture, 9 Avenue Georges V, 75008 Paris, \\ France \\ ${ }^{3}$ Cemagref, 361, Rue J.F. Breton - BP 5095 - 34196 Montpellier Cedex 5, France. \\ ${ }^{4}$ Institut National de la Recherche Agronomique, 2 Place Viala, 34060 Montpellier, France \\ ${ }^{5}$ Technical University of Lisbon, Tapada da Ajuda, 1349-017 Lisboa, Portugal \\ ${ }^{6}$ Agroscope Reckenholz-Tanikon Research Station ART, Reckenholzstrasse 191, 8046 Zurich, \\ Switzerland
}

Full address for correspondence:

A.R. Graves, Cranfield University, Cranfield, Bedfordshire, MK43 OAL, UK

E-mail address: a.graves@cranfield.ac.uk; p.burgess@cranfield.ac.uk

Key words: Cost-benefit analysis, net present value, economic analysis, economic model, equivalent annual value

\section{Abstract}

Financial feasibility and financial return are two key issues that farmers and land owners consider when deciding between alternative land uses such as arable farming, forestry and agroforestry. Moreover regional variations in yields, prices and government grants mean that the relative revenue and cost of such systems can vary substantially within Europe. To aid our understanding of these variations, the European Commission sponsored a research project called "Silvoarable Agroforestry For Europe" (SAFE). This paper describes the process of developing a new economic model within that project. The initial stages included establishing criteria for the model with end-users and reviewing the literature and existing models. This indicated that the economic model needed to allow comparison of arable farming, forestry and agroforestry systems at a plot- and a farm-scale. The form of comparisons included net margins, net present values, infinite net present values, equivalent annual values, and labour requirements. It was decided that the model would operate in a spreadsheet format, and the effect of phased planting patterns would be included at a farmscale. Following initial development, additional user feedback led to a final choice on a model name, a final method of collating input data, and the inclusion of field-based operations such as varying the cropped area, replacing dead trees, and pruning. In addition options in terms of improved graphical outputs and the ability to undertake sensitivity analysis were developed. Some of the key lessons learnt include the need to establish clear model criteria and the benefits of developing a working prototype at an early stage to gain user-feedback. 


\section{Introduction}

Increased population and increased consumption of natural resources per capita are placing increased demands on finite land resources. The ecosystem approach, popularised by the Millennium Ecosystem Assessment (2005), provides one framework for identifying the importance that different stakeholders place on the goods and services that we get from land (Agbenyega et al. 2009). However decisions regarding land use change are still primarily taken by individual land-owners, and profitability is a key consideration (Graves et al. 2009).

During the past 50 years, one of the significant land use changes across the European Union (EU) has been the removal of individual trees from agricultural land, and conversely the reestablishment of trees on agricultural land in woodland blocks. This has been partly a result of the increased mechanisation of agriculture and the availability of EU-related grants for woodland planting. One alternative method for re-establishing trees within an agricultural system is silvoarable agroforestry (Dupraz and Newman 1997; Burgess et al. 2004). It is only recently that the establishment of such systems has been supported by grants associated with the EU Rural Development Regulation 1698/2005 and, the grants are only available in some EU countries. However the decision to establish a silvoarable agroforestry system can be complex because the financial return from the tree component (in the absence of grants) can take many years, and the effect of the trees on crop yields can vary with time. Moreover the likely response will vary with tree spacing and tree species and the grants available can vary substantially between countries.

One method for determining the profitability and feasibility of silvoarable systems, relative to arable and forestry systems, is to use computer-based models (Graves et al. 2005). Although there is some literature describing the results and analyses obtained from using computer models of arable, forestry and silvoarable economics (Wojtkowski et al 1990; Thomas 1991; Willis et al. 1993; Dupraz et al. 1995; Nelson and Cramb 1998), there is less information describing the development of the models. The development of a dynamic computer-based simulation of silvoarable economics is time-consuming, and not aided by the paucity of documentation on existing computer models. This paper aims to describe the process of development of an economic model, called Farm-SAFE, and discusses some of the key lessons learnt.

\section{Method}

Within this paper, the development of an economic model of arable, forestry and agroforestry systems is described as a sequential process with significant feedback loops (Figure 1). The first action was to establish the purpose and desired features of the model with the key endusers. This was completed at the same time as a review of existing models. The third step was to develop an initial model, which was then modified in response to additional feedback through model use. 


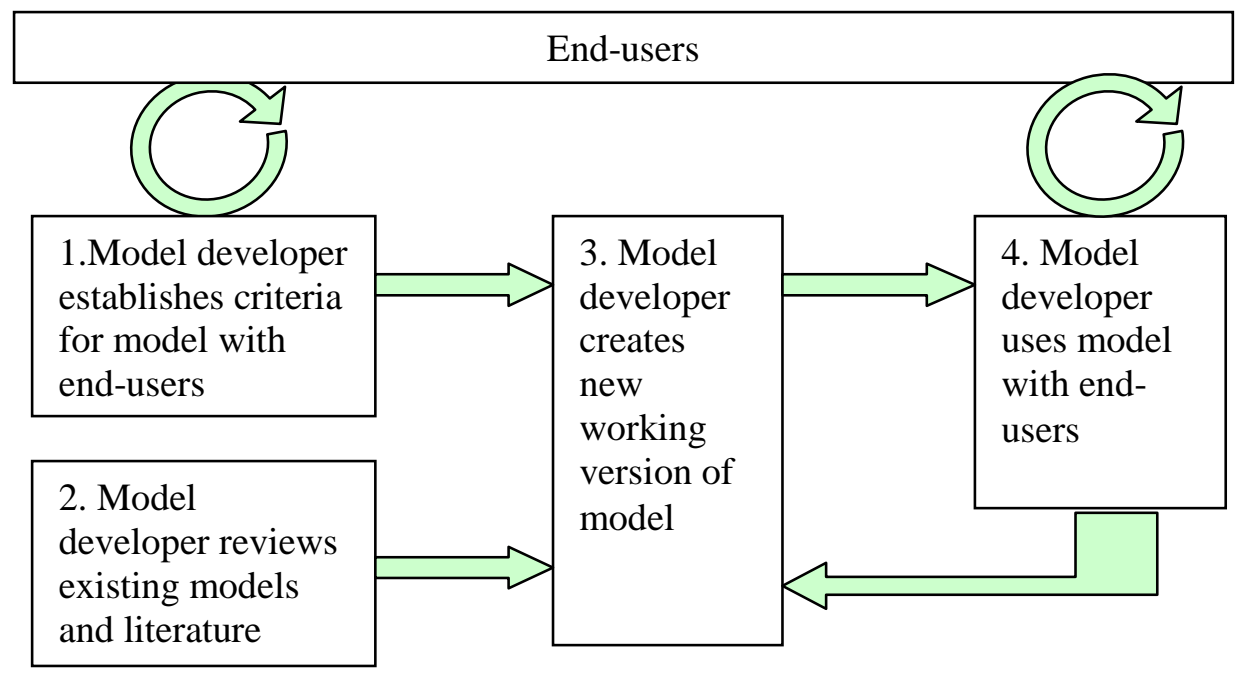

Figure 1. Schematic diagram showing how the criteria for the model, the development of the model, and its use is affected by feedback from the end-users of the model.

\section{Establishing the criteria for the model}

The primary purpose of the model was to address a research objective of an EU-sponsored project called "Silvoarable Agroforestry for Europe" which started in August 2001 and was completed in January 2005. The specific aims of the project included reducing the uncertainties concerning the viability of silvoarable systems and the extrapolation of plotscale results to individual farms (Dupraz et al. 2005). The criteria for the model were agreed at a workshop meeting including researchers and end-users in September 2002. The principal end-users were researchers and extension advisors in a range of countries including France, the Netherlands, Spain and Switzerland. The agreed criteria for the model are categorised in Table 1 using the model characteristics described by Graves et al. (2005). The criteria are categorised under the headings of: 1) model background, 2) systems modelled, 3) objective of the economic analysis, 4) viewpoint of the analysis, 5) spatial scale, 6) temporal scale, 7) generation and use of biophysical data, 8) model platform and interface, and 9) input requirements and outputs generated. 
Table 1. Criteria established for the economic model in September 2002, categorised using the framework described by Graves et al. (2005).

\begin{tabular}{|c|c|c|}
\hline \multirow{2}{*}{$\begin{array}{l}\text { Characteristic } \\
\text { 1. Background }\end{array}$} & \multicolumn{2}{|r|}{ Criteria for the economic model. The model should be able: } \\
\hline & 1.1 & To operate in English \\
\hline & 1.2 & To be initially designed and used as a research tool \\
\hline & 1.3 & To operate as a "closed" format model \\
\hline \multirow[t]{4}{*}{ 2. Systems modelled } & 2.1 & To model silvoarable, arable, and forestry systems \\
\hline & 2.2 & To model coincident and spatially-zoned silvoarable systems \\
\hline & 2.3 & To model crop rotations \\
\hline & 2.4 & To model multi-planting schemes \\
\hline \multirow[t]{5}{*}{$\begin{array}{l}\text { 3. Objectives of } \\
\text { economic analysis }\end{array}$} & 3.1 & $\begin{array}{l}\text { To use a common conceptual framework of farm economics including net } \\
\text { margins }\end{array}$ \\
\hline & 3.2 & To account for the effect of time on the value of money by discounting \\
\hline & 3.3 & $\begin{array}{l}\text { To compare the profitability of the systems. Discounted future benefits and } \\
\text { costs of each system should be aggregated and a net present value, infinite net } \\
\text { present value, and equivalent annual value calculated. }\end{array}$ \\
\hline & 3.4 & $\begin{array}{l}\text { To determine the feasibility of the systems. Discounted future benefits and } \\
\text { costs of all farm systems should be aggregated and a net present value, infinite } \\
\text { net present value, and equivalent annual value calculated. }\end{array}$ \\
\hline & 3.5 & To examine the sensitivity of each system to changes in input values \\
\hline 4. Viewpoint of analysis & 4.1 & $\begin{array}{l}\text { To simulate the view-point at a micro-economic scale, from the perspective of } \\
\text { a single farmer }\end{array}$ \\
\hline \multirow[t]{3}{*}{ 5. Spatial scale } & 5.1 & To operate at a one-hectare scale \\
\hline & 5.2 & $\begin{array}{l}\text { To operate at a farm scale. Variation in land heterogeneity and enterprise } \\
\text { diversity should be accounted for using four land units, each capable of } \\
\text { simulating one or more of an arable, forestry, and silvoarable system. }\end{array}$ \\
\hline & 5.3 & $\begin{array}{l}\text { To "establish" different areas of forestry and silvoarable systems in different } \\
\text { years }\end{array}$ \\
\hline \multirow[t]{2}{*}{ 6. Temporal scale } & 6.1 & To use a yearly time-step \\
\hline & 6.2 & To use a maximum rotation of 60 years \\
\hline $\begin{array}{l}\text { 7. Generation and use of } \\
\text { biophysical data }\end{array}$ & 7.1 & $\begin{array}{l}\text { To initially be a stand-alone model capable of using annual crop and tree yield } \\
\text { data from an external source. }\end{array}$ \\
\hline \multirow[t]{2}{*}{$\begin{array}{l}\text { 8. Platform and } \\
\text { interface }\end{array}$} & 8.1 & $\begin{array}{l}\text { To be a spreadsheet "workbook" model, using an available and inexpensive } \\
\text { modelling platform }\end{array}$ \\
\hline & 8.2 & $\begin{array}{l}\text { To use a direct interface to make it easily transferable between different } \\
\text { language versions of the software }\end{array}$ \\
\hline \multirow[t]{3}{*}{ 9. Inputs and outputs } & 9.1 & To reduce input requirements by storing key parameters \\
\hline & 9.2 . & To use databases to store key physical and financial data \\
\hline & 9.3 & To produce both tabular and graphical output \\
\hline
\end{tabular}

\section{Review existing models and literature}

At the same time as establishing the criteria for the model, we reviewed existing computer models of silvoarable economics. The principal models examined were the Agroforestry Calculator (Agriculture Western Australia and Campbell White and Associates Pty Ltd, 2000), the Agroforestry Estate Model (Knowles and Middlemiss, 1999), POPMOD (Thomas, 1991), ARBUSTRA (Liagre, 1997) and the Water Nutrients and Light Capture in Agroforestry Systems model (WaNuLCAS) (Van Noordwijk and Lusiana, 1999, 2000, 2003). Using the criteria described in Table 1, it was possible to characterise the available models and these results have been described by Graves et al. (2005).

\section{Initial development}

\section{Based on existing plot- and farm-scale models}

Although it would have been possible to start from scratch, our philosophy was to build on existing models. Of the available models, it was eventually decided to use POPMOD (Thomas, 1991) and ARBUSTRA (Liagre, 1997) as a basis for new economic model. 
POPMOD provides an empirical model of tree and crop yields to inform the economics of arable, silvoarable and poplar forestry systems at a one-hectare scale. The ARBUSTRA model, whilst lacking an empirical model of tree and crop yields, allows analysis of different combinations of agriculture/agroforestry/forestry systems within a "farm-level analysis" (Figure 2). These farm-scale features allow the analysis of the effect of different planting patterns and an assessment of the feasibility of introducing new systems in terms of capital and labour requirements (Table 2). In addition the project team had free access to and experience of using both these models and there were no copyright issues. Even so, integrating the two models involved substantial translation issues as the POPMOD model was developed in English and the ARBUSTRA model was developed in French.

Farm-scale

An area managed as one

business. Fixed costs and a

range of enterprises and

land types are typically

included
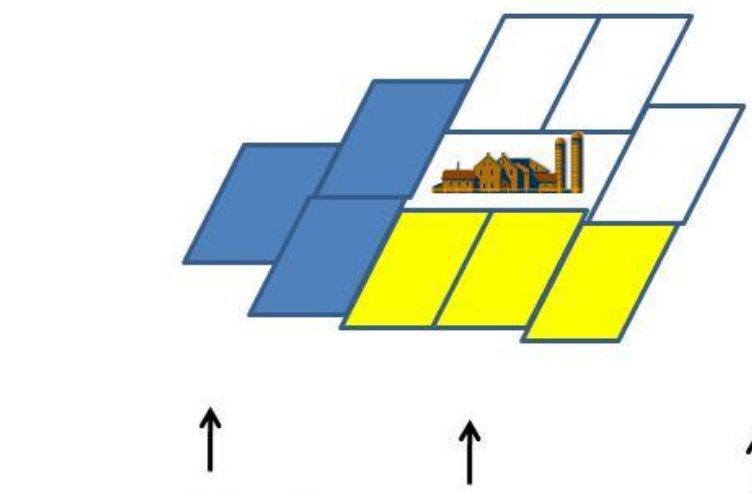

$\uparrow$
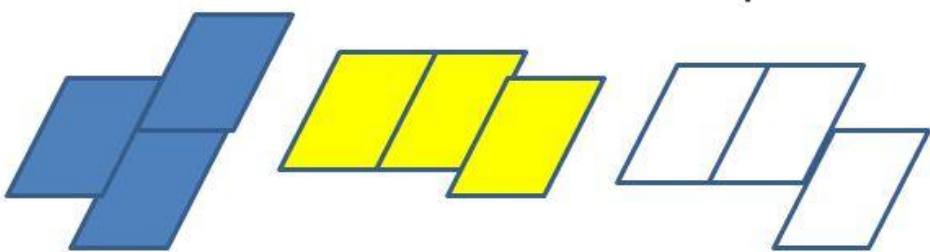

Unit-scale

A homogenous area of a specified size managed as

a unit, but potentially

including a range of

enterprises

\section{One-hectare-scale}

Homogenous area with

economic data typically

based on margins per

hectare
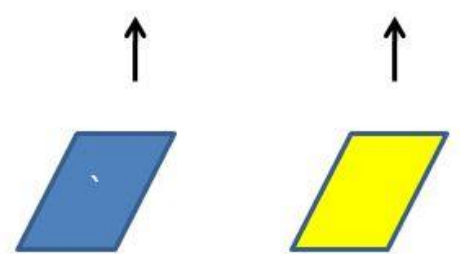

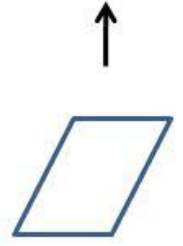

Figure 2. A schematic representation of different spatial scales of modelling, the one-hectare, unit and farm scale. A one-hectare scale analysis may be used for unit-scale analysis which in turn may be used for farm scale analysis.

Table 2. Some differences between one-hectare and farm-scale modelling.

\begin{tabular}{ll}
\hline One-hectare scale modelling & Farm scale modelling \\
\hline - Useful for comparing farm enterprises & • Useful for comparing farm profitability and labour \\
& use with and without a specified enterprise \\
- Comparison on a per unit area basis & - Comparison over a user-defined area of land \\
- Usually a single planting and clear-felling date for & - Several forestry and agroforestry planting and clear- \\
forestry and agroforestry & felling dates may be defined \\
- Spatial heterogeneity not represented & - Spatial heterogeneity represented \\
- Analysis is based on partial budgets of competing & - Analysis can include farm fixed costs \\
\hline
\end{tabular}




\section{Choice of modelling platform}

In theory it was possible to develop the model within a spreadsheet, a database, a programming language, or a graphical development environment, such as Stella ${ }^{\mathrm{TM}}$ (Systems Thinking Software ${ }^{\mathrm{TM}}$, 2005) or ModelMaker ${ }^{\mathrm{TM}}$ (ModelKinetix ${ }^{\circledR}, 2005$ ). Because the model was to be used by research and extension organisations in different countries, the platform needed to be readily available and/or inexpensive. It was also important that users could operate and modify the model themselves. Hence, it seemed optimal to use a spreadsheet platform, and specific software chosen was Microsoft ${ }^{\circledR}$ Excel. This choice was also coloured by the fact that the chosen POPMOD and ARBUSTRA model were also spreadsheet based. The decision to use a spreadsheet platform focussed on spreadsheet cell functions enabled the use of the model in different language versions (e.g. English, French, German, Italian, and Spanish). Another advantage of using a widely-used spreadsheet programme was the availability of add-on applications such as Crystal Ball@ Risk Analysis Software and Solutions (Decisioneering® Incorporated, 2005), and Insight.xla 2.0, developed by AnalyCorp ${ }^{\circledR}$ (Savage, 2003). These could be used to help in the optimization and uncertainty analysis.

\section{Form of field-scale economic analysis}

Various conceptual models of farm economics have been used depending on the circumstances and objectives of the analysis. Within the model, economic analyses were initially undertaken at a one-hectare scale (Figure 2). The financial value of each enterprise was calculated in terms of a net margin (units: $€ \mathrm{ha}^{-1}$ ) determined as the revenue ( $R$; units: $€$ $\left.\mathrm{ha}^{-1}\right)$ minus variable costs $\left(V\right.$; units: $\left.€ \mathrm{ha}^{-1}\right)$ such as seed, fertilisers and sprays, and the 'assignable fixed costs' of labour and machinery associated with the enterprise $(A$; units: $€$ ha' ${ }^{1}$ ) (Equation 1). A similar approach when comparing arable and forestry systems has previously been used by Willis et al. (1993) and Burgess et al. (1999).

$$
\text { Net margin }=R-V-A
$$

Equation 1

When comparing arable and forestry systems, whereas the costs and revenue from arable systems take place within a 12-month period, the timber revenue from trees can occur many years after the costs of establishment. Since most people have a preference for immediate income, there is an opportunity cost to immobilizing capital in long-term projects. Within the model, future benefits and costs were therefore reduced or "discounted" using the approach developed by Faustmann (1849) to value forestry investments. The net present value (NPV; units: $€ \mathrm{ha}^{-1}$ ) was therefore calculated using Equation 2 where the revenue $\left(R_{t}\right)$, variable costs $\left(V_{t}\right)$, and assignable fixed costs $\left(A_{t}\right)$ are specified for each year $(t)$ over a time horizon of $T$ (years), and $i$ is the discount rate (Equation 2):

$$
N P V=\sum_{t=0}^{t=T} \frac{\left(R_{t}-V_{t}-A_{t}\right)}{(1+i)^{t}}
$$

Equation 2

In addition in order to compare systems including tree species with different rotations, the model was also developed to calculate an infinite $N P V\left(N P V_{\text {Infinite }}\right.$; units: $\left.€ \mathrm{ha}^{-1}\right)$. This is the $N P V$ defined over an infinite time horizon, in which each replication has a rotation of $n$ years. It is defined (Equation 3) as:

$$
N P V_{\text {Infinite }}=N P V \frac{(1+i)^{n}}{(1+i)^{n}-1}
$$

The $N P V$ was also expressed as an annuity, termed the "equivalent annual value" (EAV; units: $\left.€ \mathrm{ha}^{-1} \mathrm{a}^{-1}\right)$ (Equation 4): 


$$
E A V=N P V_{\text {Infinite }} \times i
$$

Equation 4

\section{Structure of the model}

The philosophy in building the model was to develop distinct worksheets to contain the key components of the economic analysis (Figure 3; Table 3). The primary worksheet was called "Option and results" and this functioned as the control worksheet for selecting the appropriate inputs and presenting the results. This structure also simplified loading and simulation of different scenarios because each scenario could be saved, rather than needing manual input each time it was used. The input worksheets comprised three physical yield templates labelled "Arablesystem", "Forestrysystem", and "Agroforestrysystem". There were also four financial templates labelled "Arablefinance", "Treevalue", "Treegrant", and "Treecost". The inputs required in these worksheets are provided in the appendix to this paper.

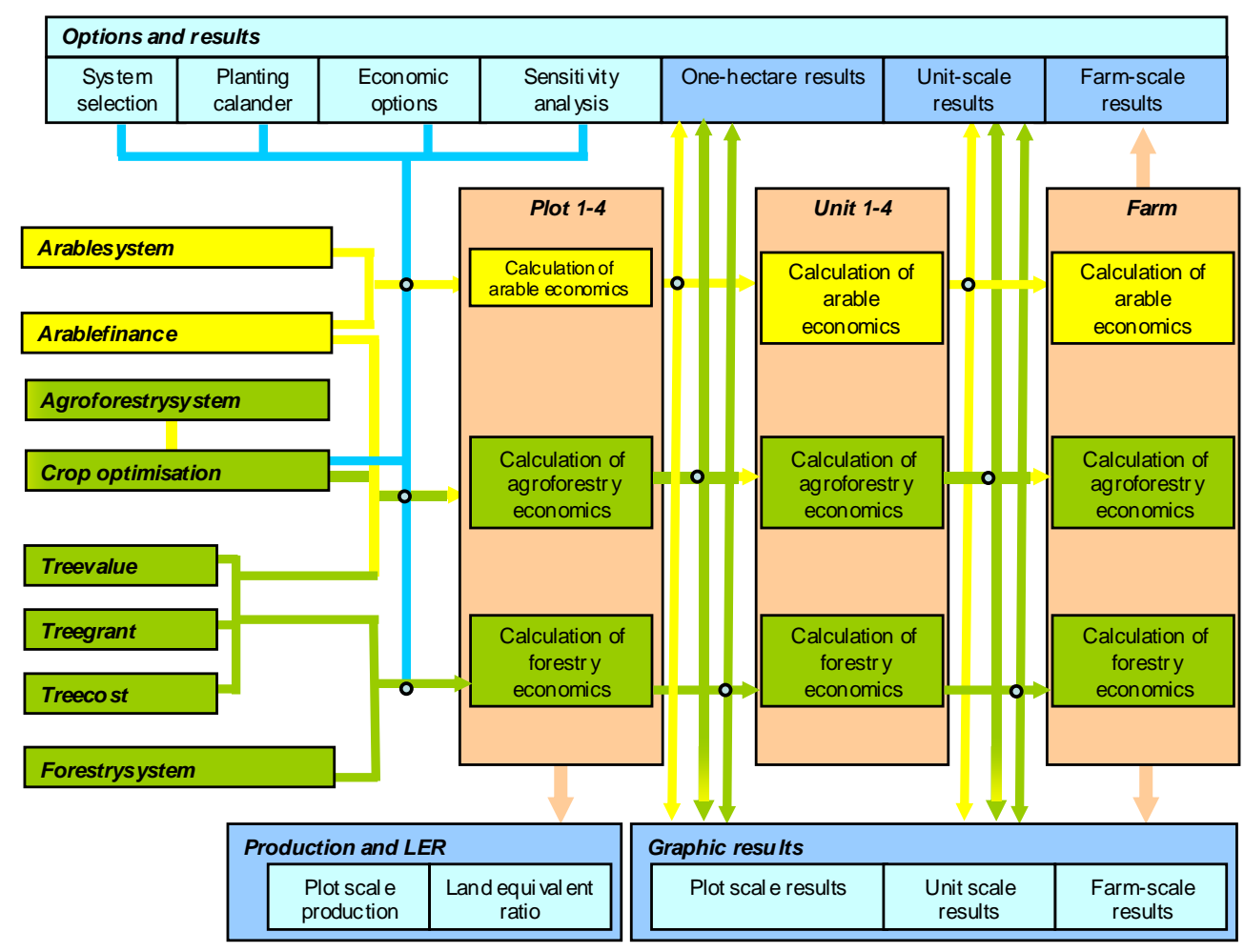

Figure 3. Schematic representation of the SAFE economic model. Each box represents a separate worksheet within the Microsoft Excel workbook. 
Table 3. Worksheets within the SAFE economic model.

\begin{tabular}{|c|c|}
\hline Worksheet name & Worksheet function \\
\hline \multicolumn{2}{|l|}{ Data manipulation } \\
\hline "Options and results" & $\begin{array}{l}\text { Allows selection of data stored in "Arablesystem", "Arablefinance", } \\
\text { "Agroforestrysystem", "Treesystem", "Treecost", "Treevalue" and "Treegrant". } \\
\text { Allows selection of analytical criteria (e.g. discount rate and rotation length) }\end{array}$ \\
\hline \multicolumn{2}{|l|}{ Data storage } \\
\hline "Arablesystem" & Stores production data for arable systems \\
\hline "Agroforestrysystem" & Stores production data for agroforestry systems \\
\hline "Forestrysystem" & Stores production data for forestry systems \\
\hline "Arablefinance" & $\begin{array}{l}\text { Stores data on the prices, grants and costs associated with arable systems and } \\
\text { the crop component of agroforestry systems }\end{array}$ \\
\hline "Treevalue" & Stores data on the prices of tree products \\
\hline "Treegr & Stores data on the grant systems associated with trees \\
\hline "Treecost" & $\begin{array}{l}\text { Stores data on the costs associated with forestry systems and the tree component } \\
\text { of agroforestry systems }\end{array}$ \\
\hline \multicolumn{2}{|l|}{ Data modelling } \\
\hline "Crop optimisation" & $\begin{array}{l}\text { For plots } 1-4 \text {, calculates the optimal rotation of the crop component of the } \\
\text { silvoarable system }\end{array}$ \\
\hline $\begin{array}{l}\text { "Plot 1", "Plot 2", "Plot 3", } \\
\text { "Plot 4" }\end{array}$ & $\begin{array}{l}\text { For four plots } 1-4 \text {, models one-hectare-scale economics and labour } \\
\text { requirements of arable, forestry and silvoarable systems }\end{array}$ \\
\hline "Unit 1", "Unit 2" "Unit 3", & $\begin{array}{l}\text { For four land units } 1-4 \text {, models unit-scale economics, labour, and land use } \\
\text { requirements of arable, forestry and silvoarable systems. }\end{array}$ \\
\hline "Farm" & $\begin{array}{l}\text { Models farm-scale economics of arable, forestry and silvoarable systems at the } \\
\text { farm scale }\end{array}$ \\
\hline \multicolumn{2}{|c|}{ Data manipulation and results } \\
\hline "Options and results" & $\begin{array}{l}\text { Stores production and economic one-hectare-, unit- and farm-scale results, in } \\
\text { numerical form as tabular data, for the final year of the rotation }\end{array}$ \\
\hline "Production and $L E R "$ & $\begin{array}{l}\text { Stores one-hectare-scale production and land equivalent ratios in graphical form } \\
\text { for the duration of the rotation }\end{array}$ \\
\hline "Graphic results" & $\begin{array}{l}\text { Stores production and economic one-hectare-, unit- and farm-scale results, in } \\
\text { graphical form for the duration of the rotation }\end{array}$ \\
\hline
\end{tabular}

\section{Form of farm-scale economic analysis}

In order to allow an analysis of the effects of introducing agroforestry or forestry systems at a farm-level, it was assumed that most farms can be described in terms of up to four land units, which each unit representing a given level of productivity. The user was required to specify the area of each land unit $\left(a_{l u}\right.$; units: ha) and this was assumed to remain constant. For example a farm may comprise one land unit of 50 ha of sandy soil and a second land unit of 100 ha of a clay soil.

In a simple comparison of forestry or silvoarable enterprises a single planting year can be assumed. However if all the planting on a large farm took place in a single year, this could cause serious disruptions to farm cash-flow and the demand for labour. Hence the economic model was designed to allow the analysis of phased planting schemes where the user could specify that a certain area or proportion of land was planted to forestry and/or silvoarable agroforestry in each year. In any particularly year $(t)$, new areas of forestry ( $a_{\text {newfor }}$ : units: ha) and silvoarable agroforestry $\left(a_{\text {newsil }}\right.$, units: ha) could be planted assuming that the total did not exceed the total area of the land unit $\left(a_{l u}\right)$. As the rotation proceeds, forestry ( $a_{\text {fellfor }}$ : units: ha) and silvoarable ( $a_{\text {fellsil }}$; units: ha) plots may also be "clear-felled" in each year. The area of forestry ( $a_{f o r}$ : units: ha) (Equation 5) and silvoarable agroforestry ( $a_{s i l}$; units: ha) (Equation 6) plots in year $t$ is therefore obtained by adding the area of new planting and subtracting the areas of clear-felled systems. 


$$
\begin{array}{ll}
\left(a_{\text {for }}\right)_{t}=\left(a_{\text {for }}\right)_{t-1}+\left(a_{\text {newfor }}\right)_{t}-\left(a_{\text {fellfor }}\right)_{t} & \text { Equation } 5 \\
\left(a_{\text {sil }}\right)_{t}=\left(a_{\text {sil }}\right)_{t-1}+\left(a_{\text {newsil }}\right)_{t}-\left(a_{\text {fellsil }}\right)_{t} & \text { Equation } 6
\end{array}
$$

Lastly the revenue and costs of up to four units were aggregated in a worksheet labelled "Farm" which also included the fixed costs of the farm $\left(F ;\right.$ units: $€$ farm $\left.^{-1}\right)$. Thus, the NPV of the farm $\left(N P V_{\text {farm }}\right.$; units: $€$ farm $\left.^{-1}\right)($ Equation 7$)$ can be expressed as:

$N P V_{\text {farm }}=\left(\sum_{l=1}^{l=4}\left(\sum_{t=0}^{t=T} \frac{\left(N_{a r}\right)_{t}\left(a_{a r}\right)_{t}+\left(N_{\text {for }}\right)_{t}\left(a_{\text {for }}\right)_{t}+\left(N_{\text {sil }}\right)_{t}\left(a_{\text {sil }}\right)_{t}}{(1+i)^{t}}\right)\right)-\sum_{t=0}^{t=T} \frac{F_{t}}{(1+i)^{t}}$

Equation 7

Where: $l$ is one of four possible land units, $N_{a r}, N_{f o r}$, and $N_{\text {sil }}$ is the net margin $\left(€ \mathrm{ha}^{-1}\right)$ of the arable, forestry and silvoarable enterprises respectively in each land unit $l$ in year $t$. The other inputs include $a_{a r}, a_{f o r}$, and $a_{\text {sil }}$ as the area (ha) of the arable, forestry, and silvoarable systems respectively in each land unit $l$ in year $t, F_{t}$ is the farm fixed cost in year $t\left(€\right.$ farm $\left.^{-1}\right)$, and $T$ is the time horizon (years). A farm infinite $N P V\left(€\right.$ farm $\left.^{-1}\right)$ and a farm $E A V\left(€\right.$ farm $^{-1} \mathrm{a}^{-}$ ${ }^{1}$ ) were also calculated with Equations 3 and 4 respectively.

The results for the one-hectare-, unit- and farm-scale calculations of timber and crop production, undiscounted and discounted cash flows, land and labour requirements were tabulated as single numerical totals for the final year of the rotation in the "Options and results" worksheet along with other criterion such as the $N P V$, infinite $N P V$, and EAV (Table $3)$.

\section{Feedback from using the model}

An initial version of the plot-scale economic model was developed within the first twelve months of the project, and a farm-scale model was developed soon after. However the model continued to be developed through the project by an iterative process of use and refinement. This was greatly aided by the development of a project website, which was used to store the project outputs and provided a forum where discussion of all aspects of the project could take place. For example, the initial version of the model with a description of the model and sample exercises was placed on the project website, so that project members could use the model and provide feedback. During the project, some of the key issues included the naming of the model, the generation and/or collation of the physical and economic data for the model, the inclusion of specific field operations, and improved ways of presenting the outputs (Table 4). 
Table 4. Additional feedback provided which led to additional features within the model.

\begin{tabular}{|c|c|c|}
\hline & Problem & Solution \\
\hline Naming & $\begin{array}{l}\text { How do you distinguish between } \\
\text { multiple models? }\end{array}$ & Provide discrete model names \\
\hline \multirow[t]{3}{*}{ Input } & $\begin{array}{l}\text { How do you minimise data entry } \\
\text { requirements? }\end{array}$ & Use "identifiers" for default datasets \\
\hline & & Collect "default" data for specific systems \\
\hline & $\begin{array}{l}\text { National differences in the subsidy } \\
\text { regime }\end{array}$ & Include a range of grant options \\
\hline \multirow[t]{5}{*}{$\begin{array}{l}\text { Field-based } \\
\text { operations }\end{array}$} & $\begin{array}{l}\text { Can you stop the crop rotation when no } \\
\text { longer profitable? }\end{array}$ & $\begin{array}{l}\text { Include a feedback loop to stop cropping } \\
\text { when unprofitable }\end{array}$ \\
\hline & $\begin{array}{l}\text { Can you include the effect of } \\
\text { establishing a grass sward? }\end{array}$ & Include effect of creating a grass sward \\
\hline & $\begin{array}{l}\text { Can you vary the cropped area during a } \\
\text { rotation? }\end{array}$ & Include the proportion of cropped land \\
\hline & $\begin{array}{l}\text { Can you include the effect of poor tree } \\
\text { establishment? }\end{array}$ & Include the impact of replacing dead trees \\
\hline & Can you include the effects of pruning? & Include pruning and pruning labour model \\
\hline \multirow[t]{4}{*}{ Output analysis } & Can you illustrate the results? & Include graphs of key outputs \\
\hline & $\begin{array}{l}\text { Can you determine the sensitivity of } \\
\text { different inputs? }\end{array}$ & $\begin{array}{l}\text { Include spreadsheet routines which allow } \\
\text { changes in key inputs }\end{array}$ \\
\hline & $\begin{array}{l}\text { Can you model one-off changes in prices } \\
\text { in a future year? }\end{array}$ & $\begin{array}{l}\text { Include spreadsheet routines to specify year } \\
\text { and degree of one-off change in prices and } \\
\text { costs }\end{array}$ \\
\hline & $\begin{array}{l}\text { Can you allow for incremental changes } \\
\text { in prices and costs from a given future } \\
\text { year? }\end{array}$ & $\begin{array}{l}\text { Include spreadsheet routines to specify year } \\
\text { and degree of incremental change in prices } \\
\text { and costs }\end{array}$ \\
\hline
\end{tabular}

\section{Naming the model and identifying its role in a family of models}

A key activity within any modelling project is identifying a suitable name for the model(s). A number of models were developed within the SAFE project and it was decided that the model name should make reference to the overall project. It was finally agreed that the plot-and farm-scale economic model would be called Farm-SAFE (Figure 4).

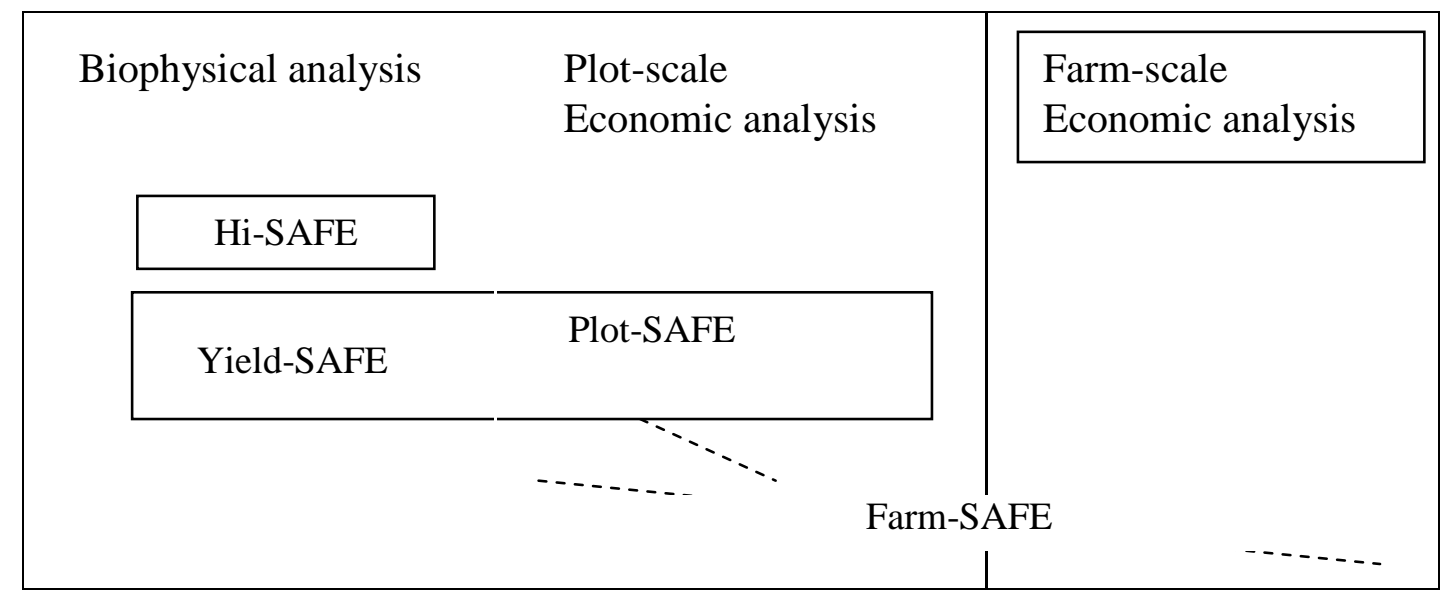

Figure 4. Schematic diagram showing the relationship between the two biophysical models, one bioeconomic model and an economic model. 
The original plan was that the economic model would use crop and tree yield data developed from a detailed stand-alone agroforestry model called Hi-SAFE. However 18 months into the project, it became clear that this biophysical model would not be available before the end of the project. Hence it proved necessary to develop a less detailed spreadsheet-based biophysical model to provide the crop and tree yield data needed for the economic analysis. This model, called Yield-SAFE, is described by van der Werf et al. (2007). In theory it would have been possible to develop a farm-scale model incorporating the Yield-SAFE model. However excessive computer memory requirements meant that it was more efficient to develop a plot-based bio-economic model called Plot-SAFE which then provided the plotscale yield, revenue and cost data needed for the farm-scale analysis.

\section{Collation of the financial data}

Some economic models, such as ARBUSTRA, require the user to enter the specific revenue and cost data for each considered system. However to simplify the process, it was clear at an early stage that "default" production and financial data should be provided for the key arable, agroforestry and forestry systems. These data were characterised by unique "identifiers" containing details of the country, region, and tree and crop type. To collate these data, financial data templates were sent to the end-users at an early stage in the project, and this was followed up by workshops with farmers and end-users in selected regions.

Within the "Arablefinance" worksheet is was generally possible to collate national or regional data on the anticipated revenue and subsidies, and the variable and assignable fixed costs associated with arable production. Where there was not possible, the costs were entered as an aggregate value. Within the "Treevalue" worksheet, the value of timber per unit volume was related to the size of the timber as timber value $\left(€ \mathrm{~m}^{-3}\right)$ typically increases as the volume of wood increases (range: $0.01 \mathrm{~m}^{3}$ to $4 \mathrm{~m}^{3}$ ) (Figure 5). Where appropriate, price data relating to firewood $\left(€ \mathrm{~m}^{-3}\right)$ and any other tree by-products $\left(€ \mathrm{t}^{-1}\right)$ were also included. The grants associated with tree establishment and management, and loss of associated agricultural income, were included in the "Treegrant" worksheet. During the project it became clear that the grants vary widely both between and within countries in the EU and it was necessary to format the template to accommodate the different procedures. The "Treecost" worksheet required data on the costs related to tree management, and also the management of the understorey vegetation within the agroforestry systems.

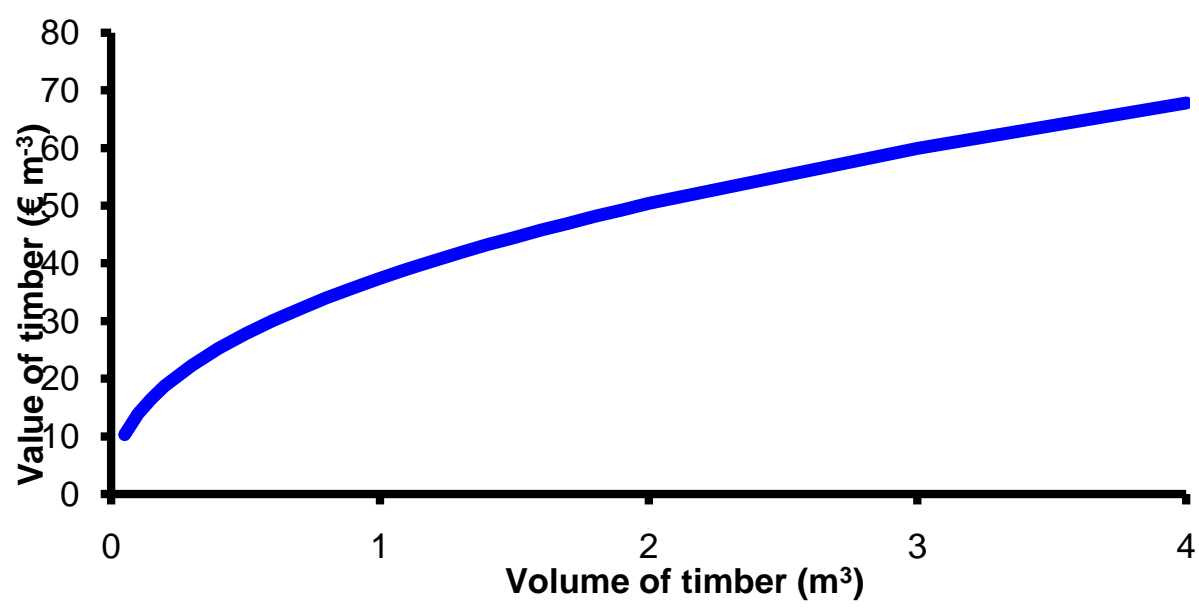

Figure 5. Predicted long-term price-size curve for the standing value of broadleaf timber in the United Kingdom based on Whiteman et al. (1991) and quoted by Hart (1994). 


\section{Addressing feedback on field-based operations}

Optimisation of arable cropping A key feature of many silvoarable systems is that the yield from the arable crop declines as the tree canopy increases and there is often a time when growing the arable crop becomes unprofitable (Graves et al., 2007; 2010). In such situations it is appropriate to examine the economics of the system assuming that the arable cropping ceases. Hence within the model, a feature was developed within the "Options and Results" worksheet to allow the user to set either a financial or physical threshold for the arable crop. To facilitate this, a crop-optimisation worksheet was added (Table 3) to calculate the optimal rotation length. Associated with the cessation of arable cropping, a common practice is to establish a grass sward below the base of the trees. Hence within the model, the option exists to specify a time to establish such a sward, together with specification of the associated labour cost (units: $€ \mathrm{~h}^{-1}$ ), labour requirement (units: $\mathrm{hr} \mathrm{ha}^{-1}$ sward) and the cost of materials (units: $€$ $\mathrm{ha}^{-1}$ sward). The model was also modified to include the cost of sward maintenance in each subsequent year.

Cropped area varying during rotation In widely-spaced silvoarable system, a farmer can also choose to reduce the proportion of the area cultivated in a specific year as the trees get larger. To account for this, an option was included within the "Options and Results" worksheet to define the relative area planted as a proportion of the total system. This value $\left(f_{c}\right)$ is typically 1 in conventional arable systems and somewhere between 0 and 1 in a silvoarable system. Because the default physical and financial data relating to the arable and silvoarable crops are expressed on a per cropped area basis, the final net margin of the arable crop $\left(N_{c}\right)$ in year $t$ must be multiplied by the proportion of area planted (Equation 8):

$$
\begin{array}{ll}
N_{c}=f_{c}(R-V-A) & \text { Equation } 8
\end{array}
$$

Replacement of dead trees In practice on many farms a certain proportion of trees will die in the initial years after planting, and their replacement can represent a significant cost. Hence the model was modified so that the user can define a number of years after tree establishment $\left(T_{\text {per }}\right)$ when a user-defined mortality rate $(m: \geq 0, \leq 1)$ is applied to all trees in the first year after planting. In each year $t$, it is assumed that the number of replacement trees, termed "beat-ups" $\left(\rho_{b}\right)$, was dependent on the number of trees planted $\left(\rho_{p l}\right)$ the previous year $(t-1)$ (Equation 9). Therefore:

$$
\text { If } T_{r} \leq T_{p e r} \text {, then } \rho_{b}=\left(\rho_{p l}\right)_{t-1} m \text { otherwise } \rho_{b}=0 \quad \text { Equation } 9
$$

Pruning In some silvoarable systems it can be profitable to side-prune the trees to maximise the volume of high-value, knot-free timber (Burgess et al. 2003). The length of the tree trunk without branches is called the "bole". Within the model, the years in which pruning occurs can be selected by the user or calculated automatically. Where calculated automatically, the bole height in a given year $n\left(\left(H_{\text {bole }}\right)_{n}\right.$; units: $\left.\mathrm{m}\right)$ was calculated as the sum of the bole height at planting $\left(\left(H_{\text {bole }}\right)_{\mathrm{t}=0}\right.$; units $\left.\mathrm{m}\right)$ and the sum of the pruning height increments since planting (Equation 10):

$$
\left(H_{\text {bole }}\right)_{n}=\left(H_{\text {bole }}\right)_{t=0}+\sum_{t=0}^{t=n} \Delta H_{\text {bole }}
$$

Equation 10

In the automated procedure, pruning was only assumed to occur if the last bole height plus a defined pruning height increment did not exceed a user-defined maximum pruning height or a 
maximum proportion of the total tree height. In addition a series of calculations were undertaken to estimate the labour cost when pruning occured. To do this the labour requirement to prune at a minimum and maximum height was defined, and the labour requirements at intermediate heights were interpolated. The cost of pruning per hectare in each year was then calculated as the product of the labour requirement ( $L_{t}$; units: minutes), a cost of labour for pruning $\left(€\right.$ minute $\left.^{-1}\right)$, and the stand density $(\rho)$.

\section{Output analysis}

Creation of graphical outputs The initial model was developed to give tabulated results (Figure 6) comprising real and discounted values of grant revenue, non-grant revenue and costs for the arable, forestry, and silvoarable enterprises at a one-hectare-, unit-, and farmscale. The results also included the associated labour requirements. Experience with using the model showed that it was often also useful to compare the results graphically, especially if comparing outputs such as cash flow or yields that varied over time (Figure 7). Similarly graphical representation was useful for examining how land use patterns might develop over time given certain planting schemes (Figure 8) and the feasibility of meeting the labour requirements associated with introducing silvoarable or forestry systems with a phased planting scheme (Figure 9).

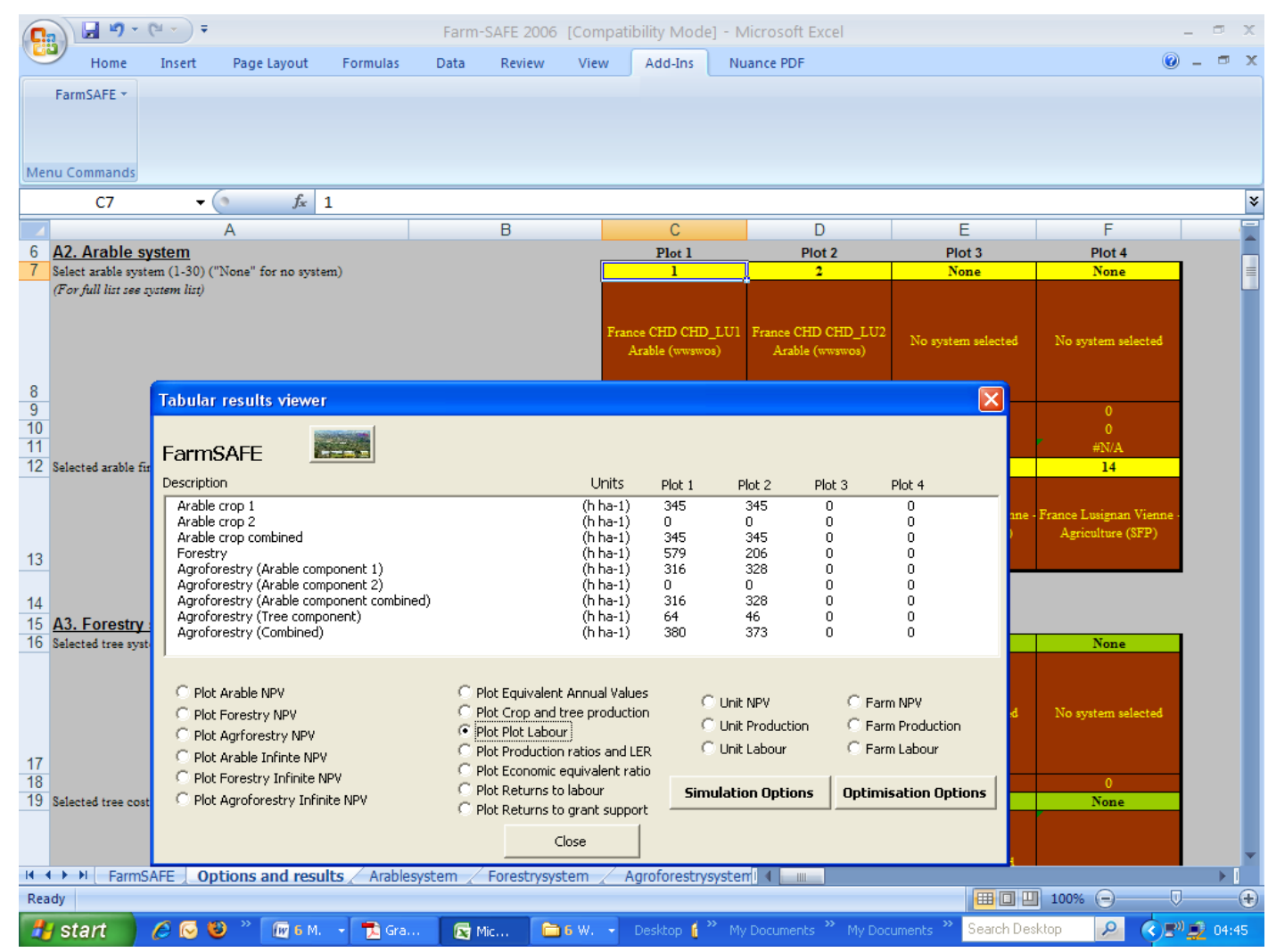

Figure 6. An example of tabular results from the Farm-SAFE model 


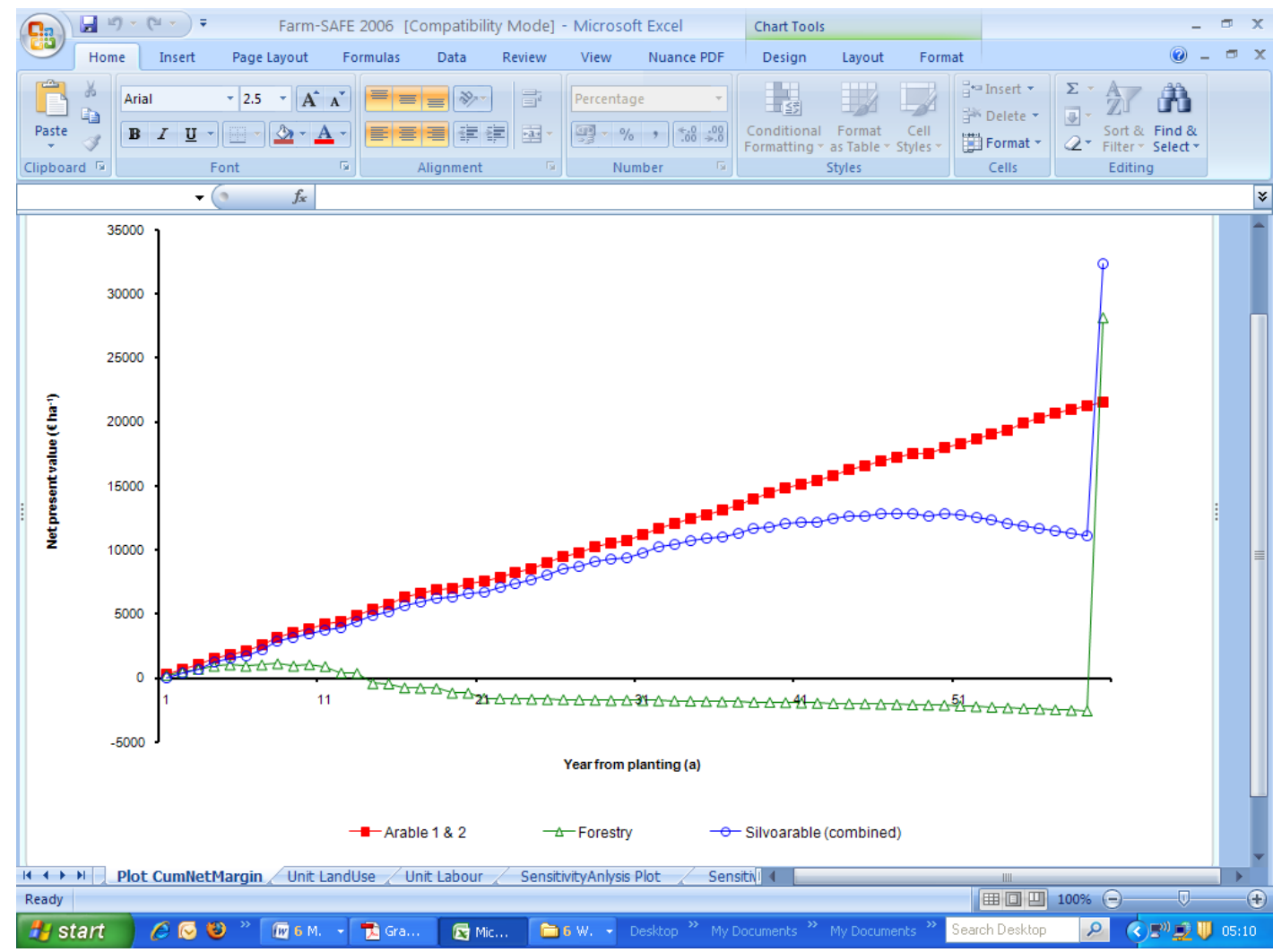

Figure 7. An example graphical result of the cumulative cash flow (discount rate $=0 \%$ ) from a simulation of an arable, forestry and silvoarable system over a 60 year period in Champdeniers in France.

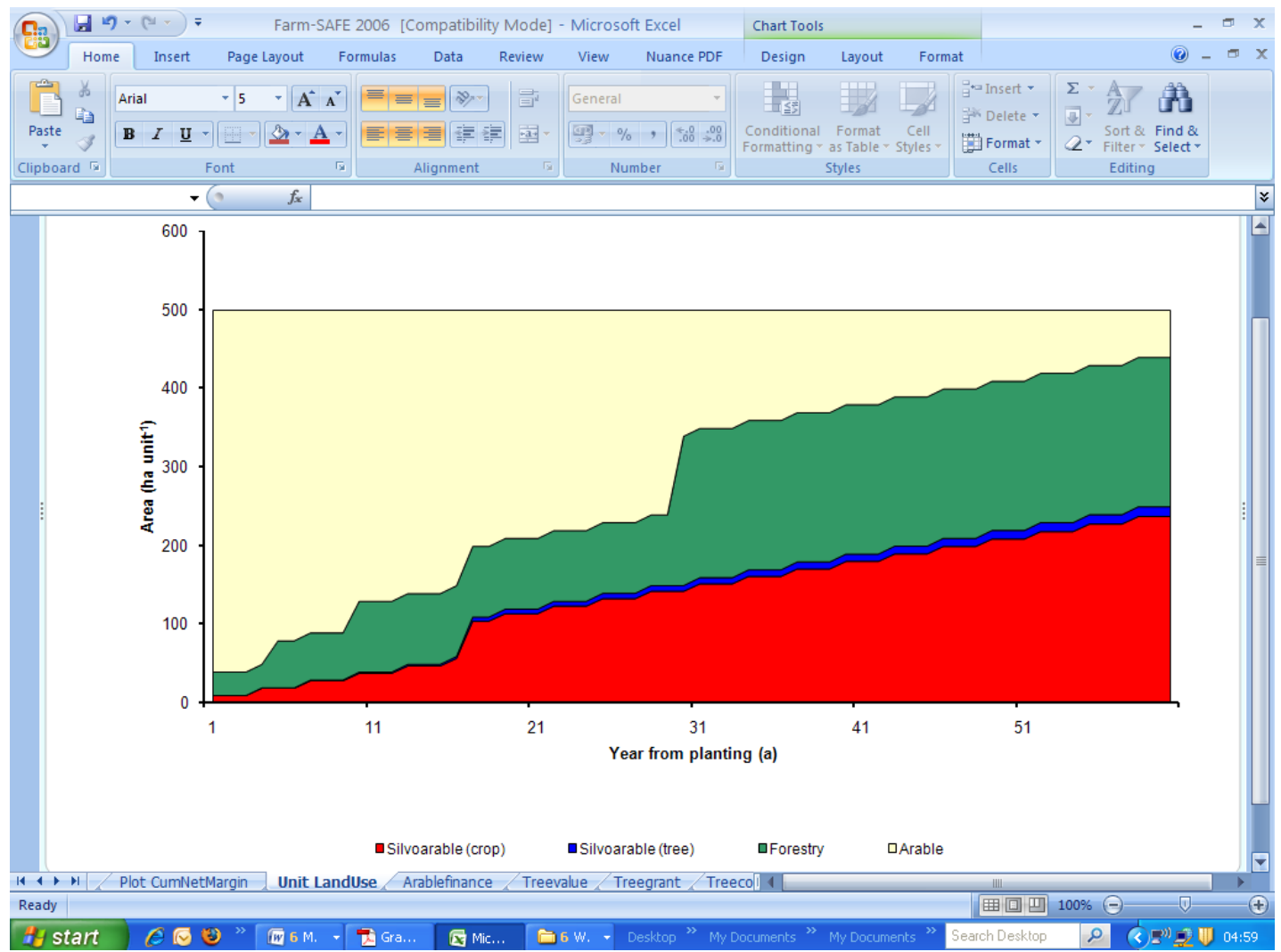


Figure 8. An example graphical result of the change in land use from a simulation of an arable, forestry and silvoarable system over a 60 year period in Champdeniers in France.

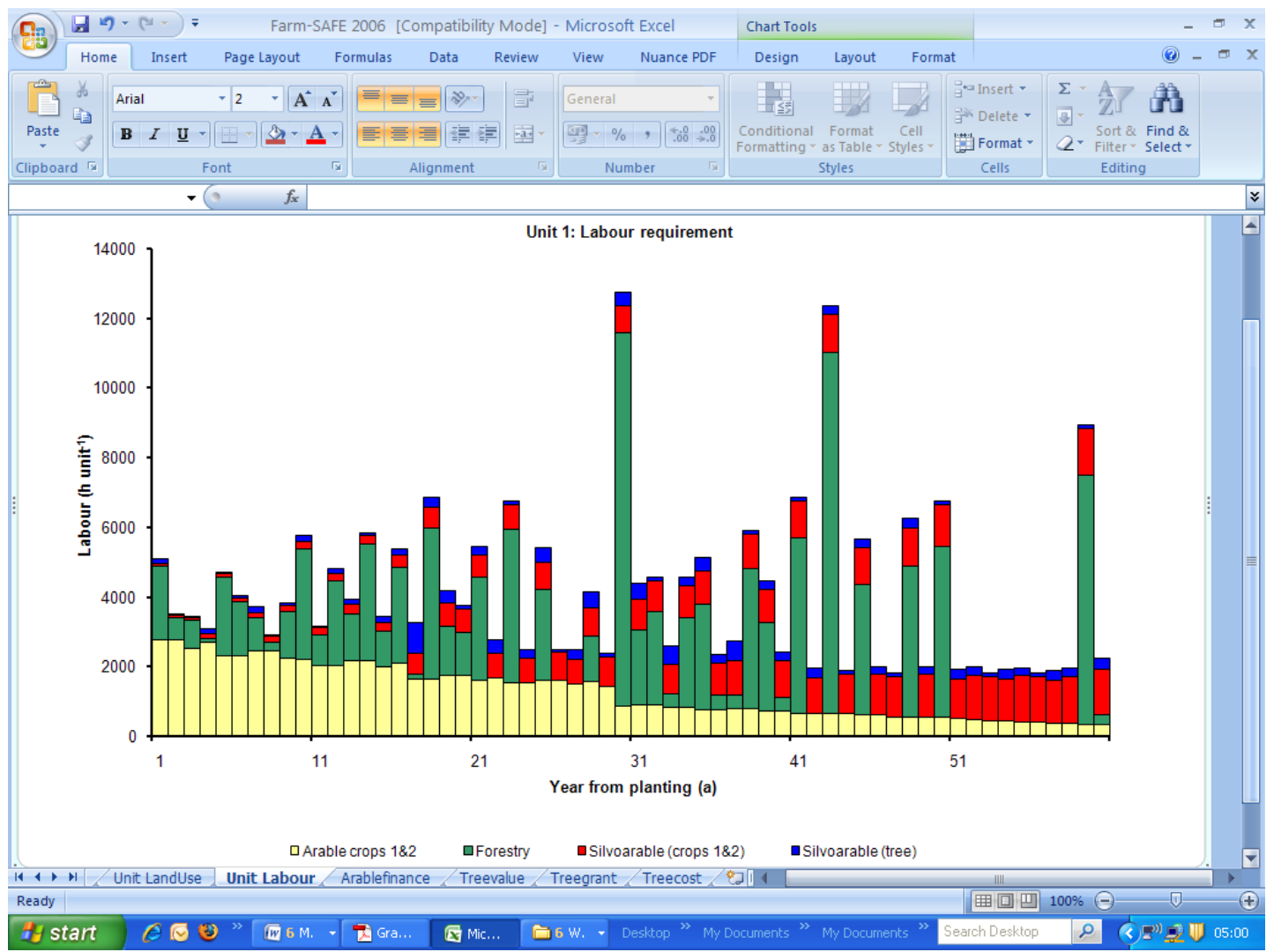

Figure 9. An example graphical result of the changes in labour use from a simulation of an arable, forestry and silvoarable system over a 60 year period in Champdeniers in France.

Examining the dynamic resource use implications of different systems may help farmers decide what is feasible. For example, in Figure 7, it is evident that the cumulative cash flows of the agroforestry and forestry systems are lower for much of the time than for the arable system, posing a challenge to farmers who want to adopt them. Farmers may also wish to consider how land use is altered over time between different land uses under different planting patterns, because this has different land use and resource use implications (Figure 8). Whilst arable systems are typified by consistent patterns of labour use, agroforestry and forestry systems are variable in their labour requirements. Farmers may want to consider how changing patterns of land use affect the pattern of labour requirements. Such requirements can prove to be a challenge, given that they are often characterises by high peaks and troughs (Figure 9).

Sensitivity to changes in yields, prices and costs One of the advantages of developing an economic model is the ability for the user to determine the sensitivity of the outputs to specific inputs (Figure 10). Within the Farm-SAFE model, user-defined changes to the relative value (typically a proportion between 0 and 2) of yields, grants, prices, labour requirements, and costs for the crop or tree components can be modelled from a specified year. Typically, different $N P V$ s for corresponding levels of relative variation in the specified input are then derived. A second option within Farm-SAFE is to examine the effect of a gradual change in a specified input (in Europe, typically a proportion between -0.1 and 0.1 ) over the entire duration of the rotation. This is useful if a consistent change in a given input is anticipated, for example, for the cost of labour or the price of timber. 
In Figure 10 which shows the NPVs of an arable, forestry, and agroforesty system under different discount rates, it is evident that lower discount rates (where the percentage change on the $\mathrm{x}$ axis is negative) correspond to high NPV for the agroforestry and forestry systems, whilst higher discount rates (where the percentage change on the $\mathrm{x}$ axis is positive) correspond to high NPVs for the arable system. The opportunity cost of capital invested in agroforestry or forestry systems is therefore an important consideration in adopting long-term systems.

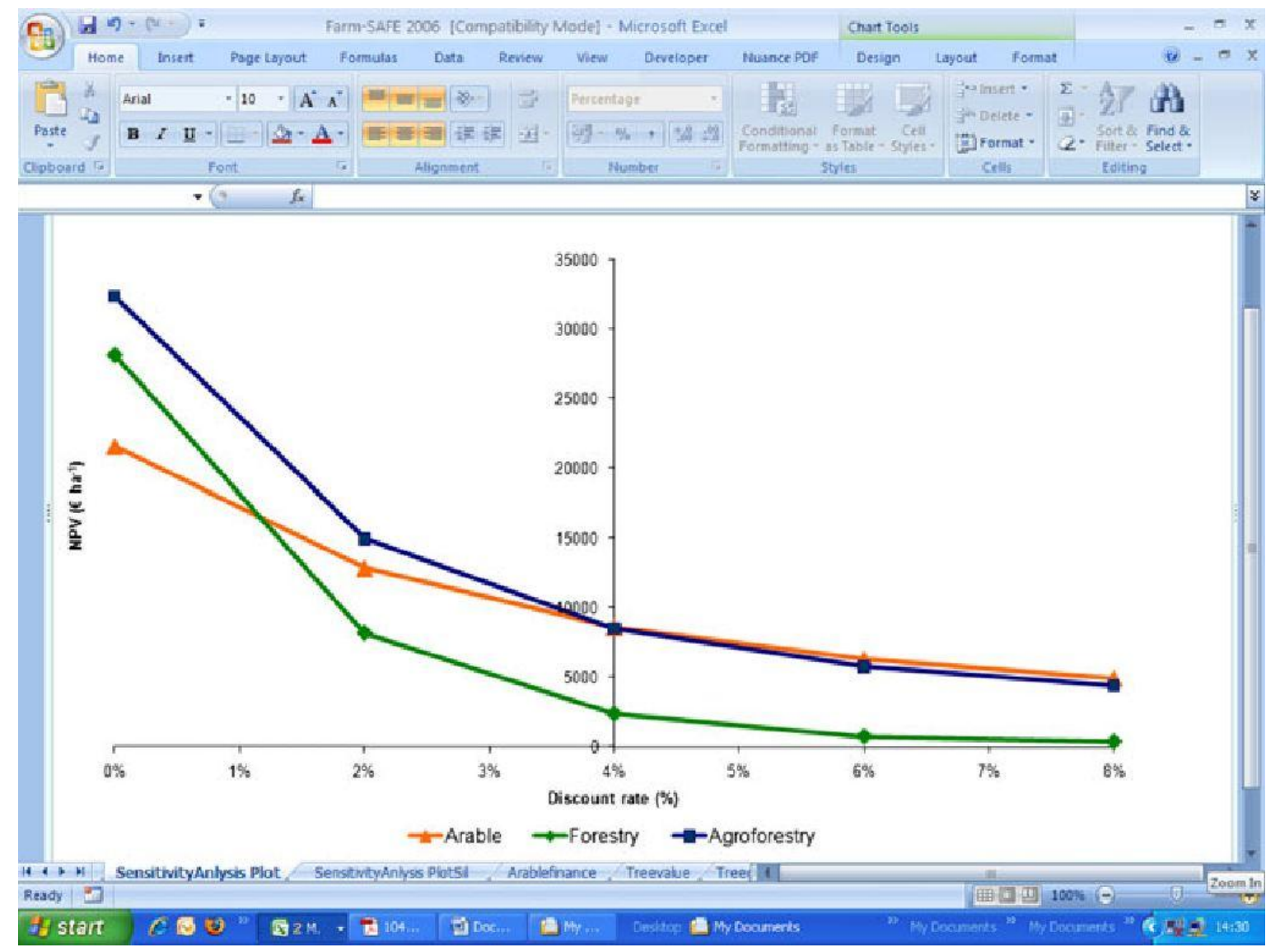

Figure 10. An example graphical result showing how discount rates affect the NPV of an arable, forestry and silvoarable system over a 60 year period in Champdeniers in France.

\section{Discussion}

It is now about five years since we originally created Farm-SAFE and a good time to reflect on what worked well in its development and what was challenging.

The development of Farm-SAFE was a collaborative success drawing on the knowledge and expertise of researchers, end-users, and field practitioners in different European countries. The model continues currently to be used in a number of European countries as well as further afield. For the reader's information, copies of the Farm-SAFE model and related documentation can be obtained free of charge from the corresponding author (contact: A.R. Graves: a.graves@cranfield.ac.uk). Documentation on the Farm-SAFE model can also be downloaded from: http://www.cranfield.ac.uk/sas/nsri/research/projects/farmsafe.html and further information on the SAFE project is available from the SAFE project website at: http://www.ensam.inra.fr/safe/ 
Working with the end-users to clearly establish the criteria for the model, and specifically recording this as a project document, was a particularly useful exercise. This allowed us to benefit from the expertise of previous model developers within the team as well as to accommodate the concerns and interests of agroforestry practitioners and enthusiasts. The document was saved and circulated to members of the project team and end-users. Whilst is served as a reference document, the criteria in it were modified as time went on, as new insight and needs emerged.

This interaction with end-users was completed at the same time as a review of existing models, which was also used to develop the criteria for plot- and farm-scale modelling (Graves et al., 2005). This review was especially important since it allowed us to borrow and develop concepts that would be useful and important within our own modelling activities.

We also reviewed the more general international literature on agroforestry, looking in particular at the criteria that influenced farmer use and adoption of agroforestry systems. A recurring theme within this is that NPV is not necessarily a criterion of evaluation for adoption, but that a variety of other socio-economic factors, such as the scale of initial investments, labour requirements and low initial cash flows can influence farmer decisionmaking (e.g. Nelson and Cramb 1998; 1998; Pannel, 1999; Graves et al., 2003). Such issues are challenging and can result in low levels of adoption and use (Mercer et al. 1998). These activities allowed us to build on what was considered to be important in the adoption and use of agroforestry systems and as far as possible, to ignore what was not considered to be important. For example, particular efforts were made to provide graphical time-series outputs of cash flow, labour requirements, and land use.

In the context of the SAFE project, we needed a robust workable biophysical model to provide time series growth data of tree and crop growth. In our particular case, the original plan of using a new detailed biophysical model did not materialise in time and it was necessary to develop a parameter-sparse biophysical model of arable, forestry and silvoarable yields (van der Werf et al., 2007) to provide Farm-SAFE with the growth data. With hindsight, the development of such a model at an earlier stage would have been useful.

This was a pan-European project with economic analyses being undertaken in France, Germany, Greece, Italy, the Netherlands, Spain and the UK. We were fortunate that, with the exception of the UK, all of the nations used a common currency. This simplified storage of the data, since this could then be done easily in a common currency, making it possible to make cross-border pan-European comparisons of the results.

The development of economic data is time consuming, and an advantage of collecting the data in a series of databases within the model is that this has ensured that the data is kept within the model for future use, ensuring that it does not become separated from the model for which it is intended. Most users seek quick answers to their questions as well as the possibility of running many different scenarios. Hence the capacity for a user to select from a database of records, for example, "wheat production in the UK", and thereby obtain a completed template of the key crop prices and costs was very useful, particularly given the large number of inputs.

By giving the model the capacity to store collections of data records, it was also possible to store scenarios, so that for example, all the physical and economic records for given arable, forestry, and silvoarable systems in a particular location could be retrieved from the various databases within the model by using the unique record identifiers to retrieve the data. This 
allowed many thousands of simulations to be run, a process that towards the end to the project was facilated through the development of Visual Basic routines that were used to automatically retrieve and manipulate data for scenario analysis.

The process of continual circulation and iterative development of the model and interaction with the end-users of the model results was essential. The most recent version of the model was often passed to various members of the project in different parts of Europe via the Internet, so that they could develop some particular feature of the model, or error check the model. In this respect strong co-ordination of the project was important, in particular as members of the scientific team were located in several countries. The fact that this was a long project, with regular meetings organised around Europe, workshops and a travel budget facilitated the process of model development through the interaction of model developers and both research oriented and field practitioner end-users of the model. Of particular importance was regular contact with field-practitioners and farmers with actual experience of agroforestry. This provided many important insights that were built into the capability of the model.

In addition to this, an important feature of the SAFE project was an extensive pan-European survey of farmers' responses to the concept of silvoarable agroforestry which allowed us to build in to the model particular features of concern to them. For example we were able to develop options to describe one-off changes in subsidy regimes or gradual changes in particular prices and costs over specific periods of time. Iterative and cyclical improvement of Farm-SAFE was essential, because the model was required to work in vastly different circumstances and because user-requirements and understanding of the systems being modelled constantly increased over the duration of the SAFE project. A project website greatly aided the development of Farm-SAFE, by facilitating the transfer of new ideas for it.

In terms of challenges, it is worth noting that on an international project, it is possible that any new model has to meet a large number of requirements. This can make the model complex and thought will need to be given to the level of complexity that can be reasonably dealt with in a single model. We found ourselves developing a number of features that were not subsequently used. This was time-consuming and added to the complexity of the interface. Clearly, establishing the true likelihood of use of a new feature is important. This also applies to simulation runs. Whilst developing automated routines within the model enabled thousands of simulations to be generated, these then became far too extensive to interpret and write up. Indeed it subsequently transpired that the important findings were in fact evident from a relatively few strategically selected scenarios.

It is worth noting that beyond being able to allocate high discount rates, risk has not been explicitly developed in the model, although it is something that is of considerable importance to farmers and other potential investors in agroforestry systems. Such risks might include the loss of the systems to fire, flood, or wind damage. In terms of possible future developments, this might be achieved through use of Monte-Carlo simulation. The model could also be used to model the welfare impacts of carbon sequestration or emissions from the different systems. This indeed might be a precursor to developing Farm-SAFE from a mirco-economic financial analysis model into a macro-economic cost-benefit analysis model that can account for the wider social implications of arable, agroforestry, and forestry systems. Finally, in purely practical terms, the development of a graphical user interface is likely to aid user interaction with the underlying model and its features, possibly allowing a wider audience to make use of it. 


\section{Conclusion}

Agroforestry is receiving renewed interest as a potential land use system in Europe. However, understanding of the economic and social implications of agroforestry systems is limited. This description of the inputs, formulae, structure, and practical issues linked to Farm-SAFE and its development will aid those intending to take this research effort forwards.

Our work started with a review of literature and existing models, and the collection of ideas from colleagues and end-users to develop our initial criteria for the model. A common conceptual framework, the net margin, was used to compare the long-term benefits of the different systems using the NPV, as well as a series of other time-series indicators, allowing users to compare the profitability and feasibility of arable, forestry, and silvoarable systems. The development of Farm-SAFE in a commonly available modelling platform facilitated its transfer and use between different members of the project team and subsequent users of the model.

Iterative and cyclical improvement of Farm-SAFE was essential, because understanding of user-requirements and the systems being modelled constantly increased over the duration of the SAFE project. A project website greatly aided the development of Farm-SAFE, by helping to transfer the model and ideas for it between colleagues on the project. The model was often passed to different members of the team to develop particular features and error check the model. However, major periods of progress also occurred during collective work on Farm-SAFE during project workshops. For this reason, it was critical that the project team were able to draw on adequate funds that enabled this interaction over an extended period of time.

Future improvements to Farm-SAFE will include consideration of risk within the model as well as a wider consideration of the relative benefits of the different land use systems, starting since Farm-SAFE makes use of annual time-step biophysical data, with an analysis of the welfare provided by carbon sequestration and leading to a full cost benefit analysis of the social costs and benefits of the different systems. At a practical level, the development of an improved interface could help a wider audience to make use of Farm-SAFE.

\section{Acknowledgements}

We are very grateful for the reviewers' feedback and suggestions. Their insight has greatly aided the development of this paper. This research was carried out as part of the SAFE (Silvoarable Agroforestry for Europe) collaborative research project. SAFE is funded by the EU under its Quality of Life programme, contract number QLF5-CT-2001-00560, and the support is gratefully acknowledged.

\section{References}

Agbenyega O, Burgess PJ, Cook M and Morris J (2009) Application of the ecosystem function framework to perceptions of community woodlands. Land Use Policy 26: 551557.

Agriculture Western Australia and Campbell White and Associates Pty Ltd. (2000) Agroforestry Calculator User Manual. A report for the Rural Industries Research and Development Corporation (RIRDC), Land and Water Resource Research and Development Corporation (LWRRDC), and Forest and Wood Products Research and 
Development Corporation (FWPRDC). RIRDC Publication No 99/154. RIRDC Project No DAW-84A. Department of Agriculture, Western Australia, Australia, 24pp.

Burgess PJ, Brierley EDR and Goodall GR (1999) The financial costs of farm woodland establishment at four sites in Bedfordshire, England. In: Farm Woodlands for the Future pp. 81-94, (eds.), P.J. Burgess, E.D.R. Brierley, J. Morris and J. Evans. Oxford: BIOS Scientific.

Burgess PJ, Incoll LD, Hart BJ, Beaton A, Piper RW, Seymour I, Reynolds FH, Wright C, Pilbeam D and Graves AR (2003) The Impact of Silvoarable Agroforestry with Poplar on Farm Profitability and Biological Diversity. Final Report to DEFRA. Project Code: AF0105. Silsoe, Bedfordshire: Cranfield University. 63 pp.

Burgess PJ, Incoll LD, Corry DT, Beaton A and Hart BJ (2004) Poplar (Populus spp) growth and crop yields in a silvoarable experiment at three lowland sites in England. Agroforestry Systems 63: 157-169.

Decisioneering® Inc. (2005). Crystal Ball 7 Risk Analysis Software and Solutions. Modelling software for spreadsheets, developed by Decisioneering ${ }^{\circledR}$, Denver, United States of America. (Accessed 9 October 2008). http://www.decisioneering.com/.

Dupraz C and Newman S (1997). Temperate agroforestry: the European way. In: A. M. Gordon and S.M. Newman (eds), Temperate Agroforestry Systems. CAB International, Wallingford, United Kingdom, pp. 181-236.

Dupraz, C., Lagacherie, M., Liagre, F. and Boutland, A. (1995). Perspectives de diversification des exploitation agricoles de la région Midi-Pyrénées par l'agroforesterie. Rapport de fin d'études commandité par le Conseil Régional Midi-Pyrénées. Institute National de la Recherche Agronomique, Montpellier. Contract AIR3 CT92-0134, 253 pp.

Dupraz, C, Burgess, P.J., Gavaland, A., Graves, A.R., Herzog, F., Incoll, L.D., Jackson, N., Keesman, K., Lawson, G., Lecomte, I., Mantzanas, K., Mayus, M., Palma, J., Papanastasis, V., Paris, P., Pilbeam, D.J., Reisner, Y., van Noordwijk, M., Vincent, G. and van der Werf, W. (2005). SAFE (Silvoarable Agroforestry for Europe) Synthesis Report. SAFE Project (August 2001-January 2005). http://www.ensam.inra.fr/safe/

Faustmann M (1849) Berechnung des Wertes Waldboden sowie noch nicht haubare Holzbestände für die Waldwirfschaft besitzen. Allgemeine Forst und Jagd-Zeitung 25: 411-455.

Graves AR, Matthew, RB, Waldie K (2004) Low external input technologies for livelihood improvement in subsistence agriculture. Advances in Agronomy 82:473-555

Graves AR, Burgess PJ, Liagre F, Terreaux JP and Dupraz C (2005). Development and use of a framework for characterising computer models of silvoarable economics. Agroforestry Systems: 65: 53-65.

Graves AR, Burgess PJ, Palma JHN, Herzog F, Moreno G, Bertomeu M, Dupraz C, Liagre F, Keesman K, van der Werf W, Koeffeman de Nooy A and van den Briel JP (2007) Development and application of bio-economic modelling to compare silvoarable, arable and forestry systems in three European countries. Ecological Engineering 29: 434-449.

Graves AR, Burgess PJ, Liagre F, Pisanelli A, Paris P, Moreno GM, Bellido M, Mayus M, Postma M, Schlindler B, Mantzanas K, Papanastasis VP and Dupraz C (2009). Farmer perceptions of silvoarable systems in seven European countries. In: Advances in Agroforestry Vol 6: Agroforestry in Europe: Current Status and Future Prospects 67-86. (Eds. A. Rigueiro-Rodríguez, J.H. McAdam, and M.R. Mosquera-Losada). Springer.

Graves AR, Burgess PJ, Palma J, Keesman K, van der Werf W, Dupraz C, van Keulen H, Herzog F and Mayus, M. (2010). Implementation and calibration of the parameter-sparse Yield-SAFE model to predict production and land equivalent ratio in mixed tree and crop systems under two contrasting production situations in Europe. Ecological Modelling 221: 1744-1756. 
Hart C (1994) Practical Forestry for the Agent and Surveyor. Stroud, Gloucestershire, UK: Sutton Publishing Ltd. 688 pp.

Knowles, L. and Middlemiss, P. (1999). Evaluating Agroforestry Options: A Continuing Professional Development Course. Forest Research, Rotura, New Zealand.

Liagre, F. (1997). ARBUSTRA Manuel de l'utilisateur. User manual for ARBUSTRA, Centre Régional de la Propriété Forestière (CRPF) and l'Institut National de la Recherche Agronomique (INRA) Montpellier, France, $71 \mathrm{pp}$

Mercer, D.E., Miller, R.P., Nair, P.K.R. and Latt, C.R. (1998). Socioeconomic research in agroforestry: progress, prospects, priorities. Agroforestry Systems 38: 177-193.

Millennium Ecosystem Assessment (2005). Ecosystems and Human Well-Being Synthesis. Washington DC: Island Press. $137 \mathrm{pp}$.

ModelKinetix $^{\mathrm{TM}}$ (2005). ModelMaker ${ }^{\circledR}$ 4.0. Modelling software developed by ModelKinetix $^{\mathrm{TM}}$, a trade name for FamilyGenetix $(\mathcal{C}$ managed by A.P. Bensen, Wallingford, Oxfordshire, England. (Accessed 9 October 2008). http://www.modelkinetix.com/.

Nelson, R.A. and Cramb, R.A. (1998). Economic incentives for farmers in the Philippine uplands to adopt hedgerow intercropping. Journal of Environmental Management 54(2):83-100.

Pannel, D. J. (1999). Social and economic challenges in the development of complex farming systems. Agroforestry Systems 45(1/3): 393-409.

Savage, S.L. (2003). Decision Making with Insight. Thomson Learning, London, United Kingdom.

Systems Thinking Software ${ }^{\mathrm{TM}}$ (2005). Stella ${ }^{\mathrm{TM}}$. Modelling software developed by ISEE, Systems Thinking Software ${ }^{\mathrm{TM}}$, Lebanon, United States of America. (Accessed 9 October 2008). http://www.hps-inc.com/.

Thomas, T.H. (1991). A spreadsheet approach to the economic modelling of agroforestry systems. Forest Ecology and Management 45: 207-235.

van der Werf, W., Keesman, K., Burgess, P.J., Graves, A.R., Pilbeam, D, Incoll, L.D, Metselaar, K., Mayus, M., Stappers, R., van Keulen, H., Palma, J \& Dupraz, C. (2007). Yield-SAFE: a parameter-sparse process-based dynamic model for predicting resource capture, growth and production in agroforestry systems. Ecological Engineering 29: 419433.

Van Noordwijk, M. and Lusiana, B. (1999). WaNuLCAS 1.0. A model of water, nutrient and light capture in agroforestry systems. Agroforestry Systems 45: 131-58.

Van Noordwijk, M. and Lusiana, B. (2000). WaNuLCAS 2.0. Background on a model of water, nutrient and light capture in agroforestry systems. International Centre for Research in Agroforestry (ICRAF), Bogor, Indonesia.

Van Noordwijk, M. and Lusiana, B. (2003). Welcome to the world of WaNuLCAS. A model of water nutrient and light capture in Agroforestry Systems. ICRAF South East Asia Programme, Bogor, Indonesia. (Accessed 9 October 2008). http://www.worldagroforestrycentre.org/sea/Products/AFModels/WaNulCAS/.

Whiteman, A., Insley, H. and Watt, G. (1991). Price-size curves for broadleaves. Occasional Paper Forestry Commission. 32:1. 36pp.

Willis, R.W., Thomas, T.H. and van Slycken, J. (1993). Poplar agroforestry: a re-evaluation of its economic potential on arable land in the United Kingdom. Forest Ecology and Management 57: 85-97.

Wojtkowski, P.A., Jordan, C.F. and Cubbage, F.W. (1990). Bio-economic modelling in agroforestry: a rubber-cacao example. Agroforestry Systems 14, 163-177 


\section{Appendices}

Table A.1. Example inputs required for model simulation and the arable and forestry in the "Options and results" worksheet.

\begin{tabular}{|c|c|c|c|}
\hline Domain & Description & Input & Unit \\
\hline All & Global options & $\begin{array}{l}\text { Total area of land units } \\
\text { Maximum length of simulation } \\
\text { Optional time-period for analysis } \\
\text { Discount rate }\end{array}$ & $\begin{array}{l}\text { ha } \\
\text { years } \\
\text { years } \\
\%\end{array}$ \\
\hline Arable & $\begin{array}{l}\text { Planting options } \\
\text { Labour cost } \\
\text { Sensitivity analysis options }\end{array}$ & $\begin{array}{l}\text { Minimum area retained in arable production } \\
\text { One labour rate for arable operations } \\
\text { Relative change to production, grants and non-grant } \\
\text { revenue and costs } \\
\text { Year of change }\end{array}$ & $\begin{array}{l}\text { ha } \\
€ \mathrm{hr}^{-1} \\
\% \\
\text { year }\end{array}$ \\
\hline $\begin{array}{l}\text { Forestry } \\
\text { And } \\
\text { silvoarable }\end{array}$ & $\begin{array}{l}\text { Discrete planting options } \\
\text { Regular plantings options }\end{array}$ & $\begin{array}{l}\text { Start year for discrete lots } 1-5 \\
\text { Area of lot } 1-5 \\
\text { Start year for each lot } \\
\text { End year } \\
\text { Interval } \\
\text { Area } \\
\text { Beating-up } \\
\text { Period of beating-up } \\
\text { Bole height at planting } \\
\text { Bole height increment at each prune } \\
\text { Max. bole height as a percentage of tree height } \\
\text { Autoprune? } \\
\text { Sixteen labour rates for different tree operations } \\
\text { Relative change to production, grants and non-grant } \\
\text { revenue and costs } \\
\text { Year of change } \\
\text { Relative single year or continuous change to grants } \\
\text { and non-grant revenue, cost and labour } \\
\text { Year of change }\end{array}$ & $\begin{array}{l}\text { year } \\
\text { ha } \\
\text { year } \\
\text { year } \\
\text { year (s) } \\
\text { ha } \\
\% \\
\text { year (s) } \\
\mathrm{m} \\
\mathrm{m} \\
\% \\
\text { yes/no } \\
€ \text { hr-1 } \\
\% \\
\text { year } \\
\% \\
\text { year }\end{array}$ \\
\hline $\begin{array}{l}\text { Forestry } \\
\text { Only }\end{array}$ & Grant modelling options & $\begin{array}{l}\text { Woodland grant system } \\
\text { Woodland grant compensation }\end{array}$ & $\begin{array}{l}\text { yes/no } \\
\text { yes/no }\end{array}$ \\
\hline $\begin{array}{l}\text { Silvoarable } \\
\text { Only }\end{array}$ & $\begin{array}{l}\text { Intercrop options } \\
\text { Grant modelling options }\end{array}$ & $\begin{array}{l}\text { Cover type when crop component is not profitable } \\
\text { Year of commencement } \\
\text { Reduction in arable area payment } \\
\text { Reduction in planting grant } \\
\text { Reduction in compensation grant }\end{array}$ & $\begin{array}{l}\text { record no. } \\
\text { year } \\
\% \\
\% \\
\%\end{array}$ \\
\hline
\end{tabular}


Table A.2. Metadata and production data required for each record in the "Arablesystem", "Treesystem" and "Agroforestrysystem" worksheets.

\begin{tabular}{|c|c|c|c|}
\hline Database name & Input function & Input names & Input values \\
\hline \multirow[t]{7}{*}{ "Arablesystem" } & Metadata (records $1-30)$ & Country; Region; Farm & (text) \\
\hline & & System & (text) \\
\hline & & Crop & (text) \\
\hline & Production data (years $1-60$ ) & Name of crop & (text) \\
\hline & & Area & $\left(\%\right.$ ha $^{-1}$ system $)$ \\
\hline & & Crop yield & (t ha ${ }^{-1}$ crop) \\
\hline & & By-product yield & (t ha ${ }^{-1}$ crop) \\
\hline \multirow[t]{11}{*}{ "Treesystem" } & Metadata (records $1-30)$ & Country; Region; Farm & (text) \\
\hline & & Tree species & (text) \\
\hline & & Yield class & (YC) \\
\hline & & Maximum bole & $(\mathrm{m})$ \\
\hline & Production data (years $0-60$ ) & Trees planted & $\left(\mathrm{ha}^{-1}\right)$ \\
\hline & & Trees harvested & $\left(\mathrm{ha}^{-1}\right)$ \\
\hline & & Mean tree height & $(\mathrm{m})$ \\
\hline & & Pruning & (yes/no) \\
\hline & & Stand volume & $\left(\mathrm{m}^{3} \mathrm{ha}^{-1}\right)$ \\
\hline & & Firewood yield & $\left(\mathrm{tha}^{-1}\right)$ \\
\hline & & By-product yield & $\left(\mathrm{t} \mathrm{ha}^{-1}\right)$ \\
\hline \multirow[t]{17}{*}{ "Agroforestrysystem" } & Metadata (records $1-23$ ) & Country; Region; Farm & (text) \\
\hline & & Tree component & (text) \\
\hline & & Crop component & (text) \\
\hline & & Maximum bole & (m) \\
\hline & Production data (years $1-60$ ) & (Crop component) & (text) \\
\hline & & Name of crop & (text) \\
\hline & & Area & $\left(\%\right.$ ha $^{-1}$ system $)$ \\
\hline & & Crop yield & (t ha ${ }^{-1}$ crop) \\
\hline & & By-product yield & (t ha ${ }^{-1}$ crop) \\
\hline & Production data (years $0-60$ ) & (Tree component) & \\
\hline & & Trees planted & $\left(\mathrm{ha}^{-1}\right)$ \\
\hline & & Trees harvested & $\left(\mathrm{ha}^{-1}\right)$ \\
\hline & & Mean tree height & $(\mathrm{m})$ \\
\hline & & Pruning & (yes/no) \\
\hline & & Stand volume & $\left(\mathrm{m}^{3} \mathrm{ha}^{-1}\right)$ \\
\hline & & Firewood yield & $\left(\mathrm{t} \mathrm{ha}^{-1}\right)$ \\
\hline & & By-product yield & $\left(\mathrm{t} \mathrm{ha}^{-1}\right)$ \\
\hline
\end{tabular}


Table A.3. Inputs required in the "Arablefinance" worksheet.

\begin{tabular}{lll}
\hline Input function & Inputs name & Input unit \\
\hline Metadata (records 1-30) & Pricing system & $($ text) \\
\hline Revenue & Grain price & $\left(€ \mathrm{t}^{-1}\right)$ \\
& By-product 1 & $\left(€ \mathrm{t}^{-1}\right)$ \\
& Area payment & $\left(€ \mathrm{ha}^{-1}\right)$ \\
\hline Variable costs & Seed price & $\left(€ \mathrm{~kg}^{-1}\right)$ \\
& Seed rate & $\left(\mathrm{kg} \mathrm{ha}^{-1}\right)$ \\
& Fertiliser price & $\left(€ \mathrm{~kg}^{-1}\right)$ \\
& Fertiliser rate & $\left(\mathrm{kg} \mathrm{ha}^{-1}\right)$ \\
& Spray price & $\left(€ \mathrm{application}^{-1}\right)$ \\
& Spray rate & $\left(\mathrm{applications} \mathrm{ha}^{-1}\right)$ \\
& Other price & $\left(€ \mathrm{unit}^{-1}\right)$ \\
& Other rate & $\left(\mathrm{units} \mathrm{ha}^{-1}\right)$ \\
& Aggregate variable cost if no breakdown & $\left(€ \mathrm{ha}^{-1}\right)$ \\
\hline Fixed costs & Fuel and repairs & $\left(€ \mathrm{ha}^{-1}\right)$ \\
& Labour & $\left(\mathrm{hr} \mathrm{ha}^{-1}\right)$ \\
& Aggregate fixed cost if no breakdown (excl. labour) & $\left(€ \mathrm{ha}^{-1}\right)$ \\
\hline
\end{tabular}

Table A.4. Input options in the "Treevalue" worksheet.

\begin{tabular}{lll}
\hline Input category & Input & Unit \\
\hline Metadata (records 1-30) & Location & $($ text) \\
& Species & (text) \\
\hline Prices & Firewood value & $\left(€ \mathrm{~m}^{-3}\right)$ \\
& By-product value & $\left(€ \mathrm{t}^{-3}\right)$ \\
& Felling value (from $0.01 \mathrm{~m}^{3}$ to $9 \mathrm{~m}^{3}$ tree $\left.^{-1}\right)$ & $\left(€ \mathrm{~m}^{-3}\right)$ \\
\hline
\end{tabular}

Table A.5. Input options in the "Treegrant" worksheet.

\begin{tabular}{lll}
\hline Input category & Input & Unit \\
\hline Metadata & Grant system & (text) \\
\hline Planting payment & Year of planting grant & $($ year) \\
& Value of planting grant & $\left(€ \mathrm{ha}^{-3}\right)$ \\
& Year of planting grant supplement & $($ year) \\
& Value of planting grant supplement & $\left(€ \mathrm{ha}^{-3}\right)$ \\
& Year of second planting grant & $\left(\right.$ year $^{-3}$ \\
& Value of second planting grant & $\left(€ \mathrm{ha}^{-3}\right)$ \\
\hline Maintenance payments & Initial year of receipt & (year) \\
& Final year of receipt & (year) \\
& Amount & $\left(€ \mathrm{ha}^{-3}\right)$ \\
\hline Compensation payments & Initial year of receipt & (year) \\
& Final year of receipt & (year) \\
& Amount & $\left(€\right.$ ha $\left.^{-3}\right)$ \\
\hline
\end{tabular}


Table A.6. Input options in the "Treecost" worksheet.

\begin{tabular}{|c|c|c|}
\hline Input category & Input & Unit \\
\hline Tree cost metadata & Location, system and species & (text) \\
\hline \multirow[t]{7}{*}{ Establishment costs } & Cost of plant & $\left(€\right.$ tree $\left.^{-1}\right)$ \\
\hline & Cost of individual tree protection & $\left(€\right.$ tree $\left.^{-1}\right)$ \\
\hline & Labour for ground preparation and weeding & $\left(\mathrm{hr} \mathrm{ha} \mathrm{a}^{-1}\right)$ \\
\hline & Labour for marking out & $\left(\mathrm{hr} \mathrm{ha}^{-1}\right)$ \\
\hline & Labour for planting trees & $\left(\min\right.$ tree $\left.^{-1}\right)$ \\
\hline & Labour for tree protection & $\left(\min \operatorname{tree}^{-1}\right)$ \\
\hline & Labour for localised weeding & $\left(\min \operatorname{tree}^{-1}\right)$ \\
\hline \multirow[t]{4}{*}{ Weeding costs } & Year of first weeding & (year) \\
\hline & Year of last weeding & (year) \\
\hline & Annual labour for weeding & $\left(\min \operatorname{tree}^{-1}\right)$ \\
\hline & Annual cost of weeding & $\left(€\right.$ tree $\left.^{-1}\right)$ \\
\hline \multirow[t]{6}{*}{ Sward costs } & Establishment of grass sward & (year) \\
\hline & Labour for grass sward establishment & (hr ha ${ }^{-1}$ sward) \\
\hline & Materials for grass sward establishment & $\left(€\right.$ ha $^{-1}$ sward $)$ \\
\hline & Final year of grass sward & (year) \\
\hline & Labour for grass sward maintenance & (hr ha ${ }^{-1}$ sward) \\
\hline & Materials for grass sward maintenance & $\left(€\right.$ ha $^{-1}$ sward $)$ \\
\hline \multirow[t]{3}{*}{ Epicormics costs } & Year of first removal of epicormics & (year) \\
\hline & Year of last removal of epicormics & (year) \\
\hline & Labour for removal of epicormics & $\left(\min \operatorname{tree}^{-1}\right)$ \\
\hline \multirow[t]{5}{*}{ Pruning cost } & Height at first prune & $(\mathrm{m})$ \\
\hline & Minutes per tree at first prune & $\left(\min\right.$ tree $\left.^{-1}\right)$ \\
\hline & Height at last prune & (m) \\
\hline & Minutes per tree at last prune & $\left(\min \operatorname{tree}^{-1}\right)$ \\
\hline & Removal of prunings & $\left(\min \operatorname{tree}^{-1}\right)$ \\
\hline \multirow[t]{2}{*}{ Maintenance costs } & Administrative cost of forestry & $\left(€ \mathrm{ha}^{-1}\right)$ \\
\hline & Insurance management & $\left(€ \mathrm{ha}^{-1}\right)$ \\
\hline \multirow[t]{2}{*}{ Thinning costs } & Marking-up and labour & $\left(\min \operatorname{tree}^{-1}\right)$ \\
\hline & Removal of tree & $\left(\min \operatorname{tree}^{-1}\right)$ \\
\hline \multirow[t]{2}{*}{ Clear-felling costs } & Labour & $\left(\min\right.$ tree $\left.^{-1}\right)$ \\
\hline & Removal of tree & $\left(\min \operatorname{tree}^{-1}\right)$ \\
\hline
\end{tabular}

